\title{
Experimental Research for Operating Thermal Electric Plant Ash in Coating Powder Production Used in the Continuous Steel Casting Lines
}

\author{
Nicolae CONSTANTIN, Valeriu RUCAI*, Bogdan FLOREA, Cristian DOBRESCU, Dragoș Florin MARCU
}

\begin{abstract}
In this paper the authors present obtaining of a technological powder used for the continuous casting of steel. The powder is applied in the casting plant distributor to ensure thermal insulation, prevent oxidation of the steel and especially to capture the steel inclusions. The powder helps to purify the steel and thus improve its quality. The paper presents the physical and chemical characteristics of the power plant ash, which is a fine-grained waste, stored in dumps and which can be used for the production of coating powders. Several experimental recipes were made, in which the proportion of power plant ash was between $65-80 \%$. To characterize the recipes, measurements were made to determine the humidity, volumetric mass, spread area, particle size analysis, melting temperature and chemical analysis. After analyzing the physical, chemical and thermal characteristics, pilot experimental batches were performed for testing in the steelworks. The favourable effects of the use of Cenoterm powder were highlighted by analyzing the slag samples taken from the experimental batches. These showed an increase in the $\mathrm{MnO}$ content of steel up to $30 \%$, an increase in alumina, magnesium and a decrease in silica. They show that the molten powders in the formed slag are reactive and play a beneficial role in the quality of the steel. Consumption of ash-based coating powder was between 0.065 and $0.22 \mathrm{~kg} / \mathrm{t}$ liquid steel.
\end{abstract}

Keywords: coating powder; continuous casting; disperser; steel; thermal electric plant ash

\section{INTRODUCTION}

Continuous improvement of the steel production requirements in terms of quality, the modernization of the steel elaboration and casting aggregates together with the developments in related technologies, lead to the implicit improvement of the disperser as part of the complex continuous casting plant equipment [1-4].

At the same time, there is a qualitative improvement in refractory materials ancillary to casting, which plays a very important role in ensuring the purity of steel through the functions they perform.

The processes that take place in the disperser during the casting of a batch, determine the purity of the steel. A proper understanding of the correlation of all technological factors contributing to superior quality of cast semimanufactures (slabs, billets, plate slabs) is the realistic approach to continuous casting procedure [5-8].

The reduction of heat loss from the steel surface occurs by using coating powders.

They must take into account the constructional features of the distributor (shape, capacity, size of the surface of the liquid steel, number of wires) and its role as an intermediate link between the casting ladle and the casting plant.

Technological powders used to cover the liquid surface of steel in the distributor are oxidative powdery materials classified as thermal insulating materials and are part of multi-component systems of the $\mathrm{SiO}_{2}-\mathrm{CaO}-\mathrm{Al}_{2} \mathrm{O}_{3}-$ $\mathrm{Fe}_{2} \mathrm{O}_{3}-\mathrm{MgO}-\mathrm{K}_{2} \mathrm{O}-\mathrm{Na}_{2} \mathrm{O}$ type and consisting of at least $15 \%$ free carbon in various forms for calorific intake and melting delay.

The performance of these powders influences the casting and solidification process of steel, including the accompanying dynamic processes, with effects on the quality of the surface and the internal structure of the continuous cast semi-finished product [2, 9-11].

The imported powder Accutherm T from Stollberg is currently used to pour large-scale slabs, for the uncovered distributor, at ArcelorMittal Galați, which has the following drawbacks:
- $\quad$ high specific consumption, $0.7-0.9 \mathrm{~kg} / \mathrm{t}$ liquid steel;

- high price;

- the deficient melting forms viscous sinters and during the sequence from the third batch, forms solidified slag bark on the steel surface, sometimes blocks the operation of the ladle-stopper;

- it reacts with the disperser lining producing corrosion that can be seen at the end of its sequence; it remains glued against the top of the unit (slag area) which leaks to the bottom of the unit blocking some steel.

The analysis of the factors that influence the quality of cast steel by increasing steel purity in the disperser constituted a second threshold in evaluation of thermodynamic and chemical processes taking place during casting from the ladle to the distributor and then into the crystallizer $[7,12,13]$.

In this respect, the conditions to be met by coating powder for the distributor and the correlation of its characteristics with the first casting parameters: steel brand, temperature and casting speed and the constructive features of the aggregate called dispenser, were established. Free carbon plays an important role in thermal insulation powders, its quantity and quality being determined by the share of free carbon-bearing matter, metallurgical coke, oil coke or charcoal but also by its quality.

Free carbon is a moderator of the melting rate of the powder and at the same time increases the thermal insulation capacity through the calorific intake resulting from its combustion.

The carbon as a chemical element is found in the metallurgical coke used in the powder, in max. $88 \%$, typically $\mathrm{C}_{\text {free }}=80 \%$, while petroleum coke, even waste, has more than $95 \%$ free carbon, so using the last type of coke, the oil one, is beneficial.

The delay by carbon of the melting process of the major oxides in the powder composition such as $\mathrm{Al}_{2} \mathrm{O}_{3}$, $\mathrm{SiO}_{2}, \mathrm{CaO}$ results in a low consumption rate, or the specific powder consumption will be lower and the thermal insulation (by stratified powder) of the steel surface will be optimal. 
As a reducing agent, $C$, especially in the presence of $\mathrm{CO}$ (formed by contact with slag oxides), can influence the quality of the steel when the powder, due to turbulence, is temporarily embedded in molten steel [7-9].

In the thermal electric plant ash, the content of iron oxides of type $\mathrm{Fe}_{2} \mathrm{O}_{3}$ is up to $10 \%$ and there is no $\mathrm{FeO}$ ferrous oxide.

The iron content of the ash is entirely in the form of $\mathrm{Fe}_{2} \mathrm{O}_{3}$ because a process of total oxidation of the fuel components takes place when the coal is burned.

The fineness of the grinding of the coke or charcoal used influences both the melting speed and the solidification range of the liquid slag. The use of ash powders, with added graphite, nanometres, if possible, increases the dust sinter-melting time, as well as a decrease in the slag solidification (vitrification) speed, which is beneficial for the steel in the disperser.

The metallurgical coke residue, used in the coating powders obtained in the present work, has compositional variations within relatively small limits.

In the coating powder manufacturing technology, a limitation of the compositional variation for raw materials is required, as follows:

- for metallurgical coke, a maximum of $10 \%$ ash is required and the free carbon is at least $90 \%$,

- for the thermal electric plant ash introduced in the raw materials recipe, contents of maximum $10 \%$ for $\mathrm{Fe}_{2} \mathrm{O}_{3}$ and maximum $20 \%$ for $\mathrm{Al}_{2} \mathrm{O}_{3}$ are required.

\section{EXPERIMENTAL RESEARCH TO OBTAIN COATING POWDERS}

2.1 Analysis of the Characteristics of the Thermal Electric Plant Ash

2.1.1 Determination of the Physical Characteristics of the Thermal Electric Plant Ash

The ash is a waste from the combustion of coal in thermal power stations, being sprayed, dry, in electro filters. The ash introduces the main oxides of the coating powder structure $\mathrm{Al}_{2} \mathrm{O}_{3}, \mathrm{SiO}_{2}, \mathrm{CaO}$ as well as carbon into the casting powder composition $[1,11,12]$.

To be used as a raw material in the molding powder technology, the ash must be kept under special ventilation conditions and without the possibility of attracting atmospheric humidity, since it is hygroscopic.

For good use, it is necessary to comply with certain values for physical characteristics, namely:

- humidity, max. $0.55 / \%$

- volumetric mass $0.60-0.65 / \mathrm{g} / \mathrm{cm}^{3}$

- $\quad$ spreading surface min. $400 / \mathrm{cm}^{2} / \mathrm{g}$

- $\quad$ sintering interval $1200-1250 /{ }^{\circ} \mathrm{C}$

- melting range $1260-1350 /{ }^{\circ} \mathrm{C}$.

Thermal electric plant ash drying is carried out in several stages, since it is warm after drying and temporarily deposited in identified bags (until dosing and mixing is carried out) it has been found to increase its humidity by more than $0.4 \%$.

Table 1 Qualitative characteristics of the ash according to its humidity

\begin{tabular}{|c|c|c|c|c|c|}
\hline Physical characteristic & \multicolumn{5}{|c|}{ Value } \\
\hline Humidity / \% & 1.05 & 0.91 & 0.59 & 0.45 & 0.40 \\
\hline Volumetric mass / g/cm $\mathrm{cm}^{3}$ & 0.87 & 0.83 & 0.71 & 0.66 & 0.58 \\
\hline Spreading surface / $\mathrm{cm}^{2} / 220 \mathrm{~g}$ & 315 & 360 & 455 & 489 & 519 \\
\hline
\end{tabular}

Several successive determinations of humidity, volumetric mass and spreading area have been carried out in the laboratory, the mean values of which are given in Tab. 1 and in the graphs in Figs. 1 to 3.

Figs. 1 to 3 show the graphical interdependence of these parameters.

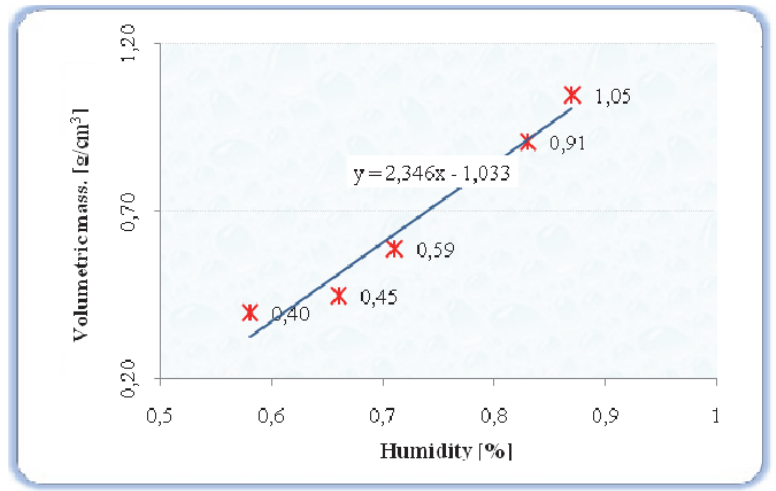

Figure 1 Increase in volume mass when increasing humidity

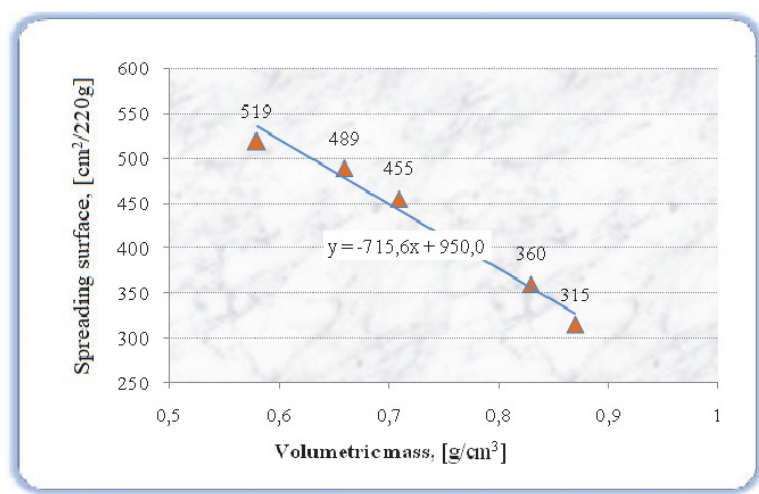

Figure 2 Decrease in ash discharge capacity when increasing volume

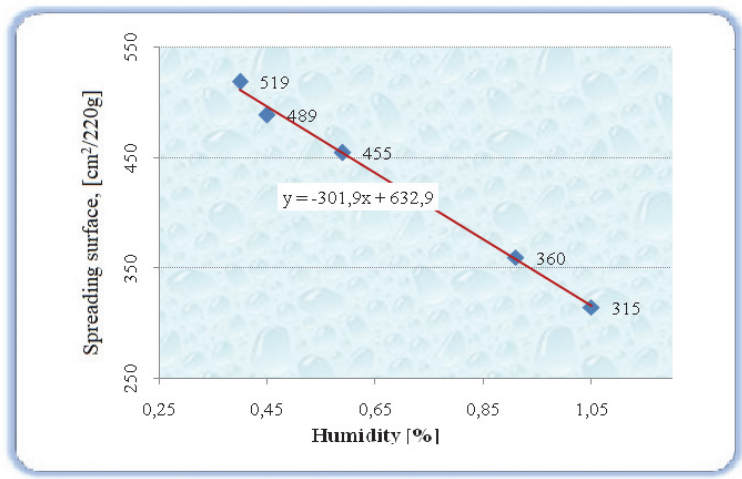

Figure 3 Influence of humidity on the ash spreading area

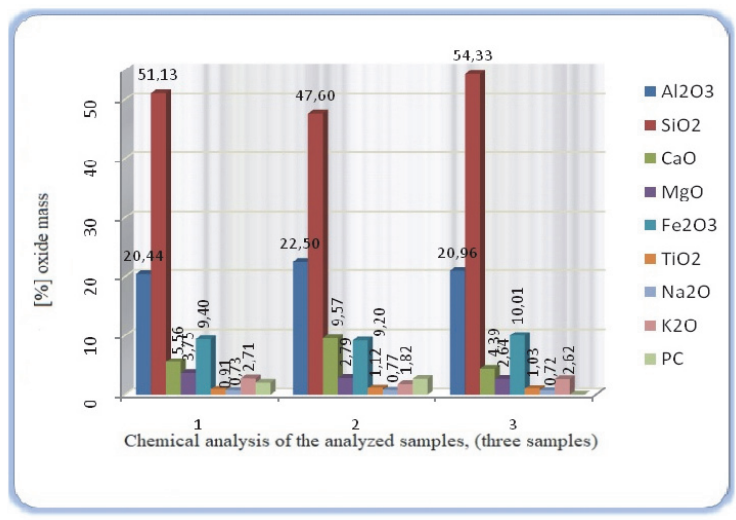

Figure 4 Compositions of the thermal electric plant ash 
It can be observed that the humidity has a negative effect on the spreading capacity and the bulk mass/volumetric mass of the ash, as well.

The chemical compositions of thermal electric plant ash from Doicești were determined in the laboratory and are shown in Fig. 4 [2, 4].

\subsubsection{Analysis of the High Temperature Performance of Doicesti Thermal Electric Plant Ash}

Using a furnace in which the evolution of the temperature can be perfectly controlled, as laboratory furnace coupled with an optical microscope that visualizes the sample inside the furnace, the high-temperature behavior of Doicesti-source thermal electic plant ash was investigated.

Microscopic images of the ash sample, which is heated up to $1358^{\circ} \mathrm{C}$, are shown in Fig. 5 .

It is noted that it deforms as the temperature increases.
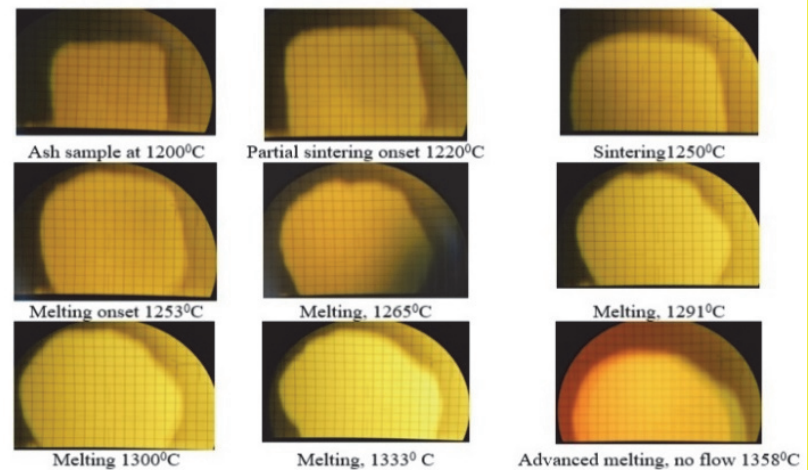

Figure 5 Microscopic images of the ash sample during determinations [1]

Analysis of high temperature optical microscopy images shows that the ash, on melting, does not become fluid, remains viscous, and there is no regular flow for an oxidizing material. No image of the flattened half sphere, typical of flow.

The appearance of this melted ash is glossy-free, dark gray to black, and the melt easily detaches from the support plate upon which it melted.

Generally, the so-called "fly ash" casting powders melt harder, have higher viscosity and lower melting speed.

Ash is still an important raw material, with a large share in the composition of casting powders (still predominantly used in powder technology in Europe) due to the following advantages:

- it is a cheap raw material.

- found in a powdery or pulverization state, using it as such and no longer requires additional energy consumption for grinding.

- has good flow and spreading properties.

- it can be transported pneumatically, directly to the storage bunkers.

The chemical composition ensures the presence of the main refractory oxides: $\mathrm{SiO}_{2}, \mathrm{Al}_{2} \mathrm{O}_{3}$ and small amounts of basic oxides: $\mathrm{CaO}, \mathrm{Na}_{2} \mathrm{O}, \mathrm{K}_{2} \mathrm{O}[2,4]$.

The ash melts heavily, the molten state is viscous; it has a sinter-melting range of approximately $1000{ }^{\circ} \mathrm{C}$, which is ideal for the ash used in the casting of steel.

\subsection{Experimental Laboratory Research to Produce the Coating Powder Using the Thermal Electric Plant Ash as Raw Material}

The most used coating powders for the dispenser have acid composition.

Accutherm $\mathrm{T}$ and Accutherm $\mathrm{T} 20$ powders are acidic powders containing silica $\left(\mathrm{SiO}_{2}\right)$ and alumina $\left(\mathrm{Al}_{2} \mathrm{O}_{3}\right)$ more than $70 \%$.

Thermal electric plant ash powders have higher silica content than these powders and lower alumina content.

Being a mechanical mixture of oxidizing materials, it has physical and chemical properties determined by its components; the physical characteristics are transmitted to the finished product in proportion to their weight. Chemical reactions between components occur on melting, certain networks of silicoaluminates are formed which can incorporate and dissolve various steel inclusions, usually oxides but also sulphides or sulphates formed earlier.

The formation of the $\mathrm{SiO}_{2} \mathrm{MgO}$ or $\mathrm{SiO}_{2} \mathrm{Al}_{2} \mathrm{O}_{3}$ refractory spinels increases viscosity and density of slag.

For this reason, the slag is usually removed from the dispenser at least once per batch to take the viscous slag down.

By subsequent application of the coating powder, a new slag is formed by partial melting upon contact with the steel bath, which is fluid and capable of capturing other inclusions or of retaining any trace of gases.

The characteristics of the powder, both as a powder and as a melt in liquid slag, determine its behaviour at the interface with steel.

Chemical analysis of the components helps to establish the approximate scope of the application, but also to assess the thermal characteristics and the mode of melting behaviour.

The alumina, magnesia, and silica compositions free of founding oxides such as $\mathrm{Na}_{2} \mathrm{O}$ and $\mathrm{K}_{2} \mathrm{O}$, even $\mathrm{Fe}_{2} \mathrm{O}_{3}$, will have high sinter-flow temperatures; those with silica and alumina, i.e., the thermal electric plant ash powders have melting temperatures around $1280^{\circ} \mathrm{C}$.

The experimental recipes are presented in Tab. 2.

Table 2 Recipes for raw materials to produce coating powder

\begin{tabular}{|c|c|c|c|c|}
\hline Materials/Recipes & $R_{\mathrm{I}}$ & $R_{\mathrm{II}}$ & $R_{\mathrm{III}}$ & $R_{\mathrm{IV}}$ \\
\hline $\begin{array}{c}\text { Thermal electric plant } \\
\text { ash }\end{array}$ & $70-80 \%$ & $70-80 \%$ & $60-70 \%$ & $65-75 \%$ \\
\hline $\begin{array}{c}\text { Expanded perlite- } \\
\text { perlysol assortment }\end{array}$ & $5-15 \%$ & $10-20 \%$ & $15-25 \%$ & $10-20 \%$ \\
\hline $\begin{array}{c}\text { Metallurgical coke } \\
\text { residue }\end{array}$ & $15-25 \%$ & $10-20 \%$ & - & - \\
\hline Oil cokes & - & - & $15-20 \%$ & - \\
\hline Charcoal waste & - & & - & $15-25 \%$ \\
\hline
\end{tabular}

The main physical characteristics of the experimental materials are presented in Tab. 3 .

Table 3 Physical characteristics of the raw materials used [1]

\begin{tabular}{|c|c|c|c|c|}
\hline $\begin{array}{c}\text { Material } \\
\text { name/ } \\
\text { Feature }\end{array}$ & $\begin{array}{c}\text { Humidity } \\
/ \%\end{array}$ & $\begin{array}{c}\text { Volumetric } \\
\text { mass } \\
/ \mathrm{g} / \mathrm{cm}^{3}\end{array}$ & $\begin{array}{c}\text { Dispersal } \\
\text { surface } / \\
\mathrm{cm}^{2} / 220 \mathrm{~g}\end{array}$ & $\begin{array}{c}\text { Granulometry, } \\
/ \%\end{array}$ \\
\hline $\begin{array}{c}\text { Ash - } \\
\text { Doiceşti } \\
\text { source }\end{array}$ & 0.31 & 0.55 & 560 & $\begin{array}{c}100 \%<1.0 \\
\mathrm{~mm}\end{array}$ \\
\hline $\begin{array}{c}\text { Metallurgical } \\
\text { cokes }\end{array}$ & 0.72 & 1.0 & 230 & $\begin{array}{c}80 \%<0.09 \\
\mathrm{~mm} ; 20 \%<1.0\end{array}$ \\
\hline $\begin{array}{c}\text { Perlite- } \\
\text { perlysol }\end{array}$ & 0.70 & 0.12 & 3070 & $\begin{array}{c}\mathrm{Min} 15 \%>1 \\
\mathrm{~mm} ; \max 85 \% \\
<1.0\end{array}$ \\
\hline
\end{tabular}


To characterize the recipes, determinations were made for humidity, volumetric mass, dispersal surface, particle size analysis, melting temperature and chemical analysis. The results of the determinations performed are presented in Tabs. 4 and 5.
In the graph in Fig. 6 the spreading surfaces of the experimental samples are presented in a suggestive manner compared to the Roeno TTC dust - the reference dust from MECHEL Targoviste.

Table 4 Physical characteristics of experimental recipes

\begin{tabular}{|c|c|c|c|c|c|c|c|c|}
\hline \multirow{2}{*}{ Powder type } & \multicolumn{4}{|c|}{ Particle size analysis / \% } & \multirow[b]{2}{*}{$\begin{array}{l}\text { Volumetric mass / } \\
\qquad \mathrm{g} / \mathrm{cm}^{3}\end{array}$} & \multirow{2}{*}{$\begin{array}{c}\text { Dispersal } \\
\text { surface / } \\
\mathrm{cm}^{2} / 220 \mathrm{~g}\end{array}$} & \multirow[b]{2}{*}{$\begin{array}{l}\text { Humidity } \\
/ \%\end{array}$} & \multirow{2}{*}{$\begin{array}{c}\text { Melting } \\
\text { temperature, } \\
/{ }^{\circ} \mathrm{C}\end{array}$} \\
\hline & $\begin{array}{c}1.0-0.5 \\
/ \mathrm{mm}\end{array}$ & $\begin{array}{c}0.5-0.09 \\
/ \mathrm{mm}\end{array}$ & $\begin{array}{c}0.09-0.06 / \\
\mathrm{mm}\end{array}$ & $\begin{array}{l}<0.06 \\
/ \mathrm{mm} \\
\end{array}$ & & & & \\
\hline$R_{\mathrm{I}}$ & 1.6 & 11.2 & 8.4 & 62.8 & 0.51 & 854.4 & 0.41 & 1200 \\
\hline$R_{\mathrm{II}}$ & 3.2 & 10.1 & 8.7 & 61.2 & 0.42 & 977.3 & 0.37 & $1200-1220$ \\
\hline$R_{\mathrm{III}}$ & 3.7 & 10.3 & 6.8 & 60.4 & 0.45 & 862.1 & 0.19 & $1230-1250$ \\
\hline$R_{\mathrm{IV}}$ & - & 2.8 & 9.2 & 64.8 & 0.58 & 629.5 & 0.47 & $1200-1220$ \\
\hline $\begin{array}{l}\text { Roeno TTC } \\
\text { 5/10 Rolleke }\end{array}$ & \multicolumn{2}{|c|}{ over $40 \%>0.5$} & \multicolumn{2}{|c|}{ cca. $60 \%>0.09$} & 0.41 & 497.8 & 0.15 & 1300 \\
\hline
\end{tabular}

Table 5 Chemical analysis of the experimental recipes

\begin{tabular}{|c|c|c|c|c|c|c|c|c|c|c|}
\hline \multirow{2}{*}{ Powder type } & \multicolumn{10}{|c|}{ Chemical composition ${ }^{*} / \%$} \\
\hline & $\mathrm{CaO}$ & $\mathrm{Al}_{2} \mathrm{O}_{3}$ & $\mathrm{MgO}$ & $\mathrm{SiO}_{2}$ & $\mathrm{Fe}_{2} \mathrm{O}_{3}$ & $\mathrm{Na}_{2} \mathrm{O}$ & $\mathrm{K}_{2} \mathrm{O}$ & $\mathrm{TiO}_{2}$ & $\mathrm{C}_{\text {lib }}$ & P.C. \\
\hline$R_{\mathrm{I}}$ & 7.60 & 14.29 & 2.64 & 49.08 & 5.97 & 1.45 & 2.32 & - & 16.53 & 16.6 \\
\hline$R_{\mathrm{II}}$ & 6.36 & 14.96 & 2.95 & 52.16 & 6.32 & 1.13 & 2.41 & - & 11.43 & 13.7 \\
\hline$R_{\text {III }}$ & 3.92 & 17.11 & 4.02 & 45.19 & 5.92 & 0.98 & 2.52 & - & 13.52 & 20.3 \\
\hline$R_{\mathrm{IV}}$ & 3.57 & 15.00 & 3.00 & 48.16 & 6.52 & 0.79 & 2.73 & 0.63 & 11.15 & 19.6 \\
\hline $\begin{array}{c}\text { Roeno TTC } \\
5 / 10\end{array}$ & 0.95 & 5.86 & 0.84 & 89.9 & 0 & 0.08 & 2.17 & - & 4.50 & 0.20 \\
\hline Accutherm T & 2.5 & 19.5 & 1.6 & 35.5 & 6.5 & 5.3 & - & - & 18.0 & - \\
\hline Accutherm T5 & 4.0 & 21.5 & 1.6 & 41.5 & 7.0 & 5.5 & - & - & 6.0 & \\
\hline
\end{tabular}

* The carbon was analysed separately, the initial samples were calcined, and the calcination losses, P.C. have resulted.

Experimental laboratory research on the physical properties of the casting powders made from the presented recipes highlighted the following aspects:

- The humidity as the reference parameter for agglomeration process, the most common defect in all casting powders, had very low values for the samples taken from the test batch. The moisture readings were below the maximum value, $R_{\text {III }}$, of $0.47 \%$.

- The volumetric mass, the property on which depend both the thermal insulation capacity of the steel meniscus and its degree of scattering and coating, has shown very good values, below $0.5 \mathrm{~g} / \mathrm{cm}^{3}$, except for the third recipe which had the mass of $0.58 \mathrm{~g} / \mathrm{cm}^{3}$, under the influence of higher humidity than the others.

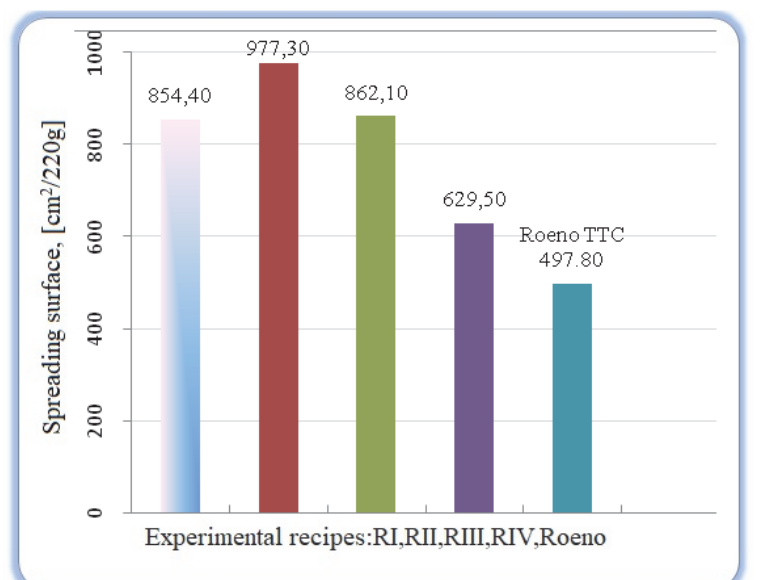

Figure 6 Dispersal surfaces for experimental recipes and reference powder

A lower value of humidity determines a lower value of the volumetric mass of the sample.

The "light" and dry masses have a very good ability to discharge and disperse, thus ensuring an efficient thermal insulation.
Fig. 7 shows the values of the preponderant oxide compounds and combustible parts for made powder recipe.

The melting temperatures have been found to be in the low range of 1200 to $1250{ }^{\circ} \mathrm{C}$, and in this respect need to be experienced by the addition of calcium oxide or by increasing the content of metallurgical coke.

The $R_{\mathrm{III}}$ recipe has the highest melting temperature of the prepared recipes.

The coke used is different from blast furnace coke, it has been contaminated with sand and therefore all recipes have shown a low melting temperature.

The chemical analysis of the recipes reflects the compositional dosage for experimental powder and is crucial for the use behaviour of each powder.

Analysis of results values given in Tab. 5 leads to the following assessments:

- the values of $\mathrm{Al}_{2} \mathrm{O}_{3}$ are around $15 \%$, (max. $17.11 \%$ for $R_{\mathrm{III}}$ ) and show (theoretically at least) that the powder has the capacity to capture inclusions and is not saturated in alumina. Accutherm $\mathrm{T}$ powder has alumina values of around $20 \%$, but $\mathrm{Na}_{2} \mathrm{O}$ content is over $5 \%, \mathrm{Na}_{2} \mathrm{O}$ is a very good flux and fluidizer on the silicate grid;

- $\quad$ low values of $\mathrm{MgO}$, below $4.0 \%$ which may mean that the melt will have a low viscosity (increasing the $\mathrm{MgO}$ ratio increases viscosity);

- the content of iron oxides is below $6.5 \%$, which for powder obtained from ash is the limit of a good composition;

- free carbon has much higher values than Roeno TTC powder with 5-12\%, but comparable to Accuherm T powder. For powder used in the dispenser, restrictions on carbon content very rarely exist when pouring a pearlitic steel, with very low carbon content, susceptible to crust carburization; 
- the values of physical and chemical characteristics determined for the experimental recipes compared to the imported powder from Rolleke, Roeno TTC 5/10 which were presented in Tabs. 4 and 5, are different. The high content in $\mathrm{SiO}_{2}$ shows that the powder is very strongly acidic, siliceous, the composition of which is different from that of the experimental silicoaluminous powder.

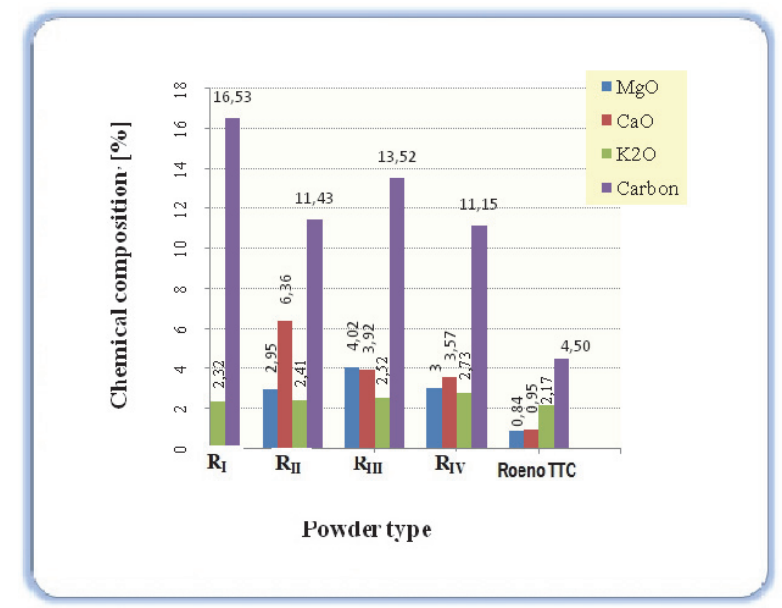

Figure 7 Values of the preponderant oxide compounds and combustible parts for the made powder recipes

The visual appearance of the powder is that of a mass of rice husks mixed with graphite flakes, a powder like the Thermostil type.

The disadvantage of this powder is that at the melting it forms very little slag, the thickness of the layer being insufficient to capture and incorporate the slag inclusions.

The analysis of made compositions to select a recipe with the best characteristics is based on their values and the $R_{\mathrm{III}}$ recipe can be considered to have the best physical and thermal characteristics and the chemical composition shows a less acid composition than the others.

The finalization of the coating powder technology for the disperser, the powders based on thermal electric plant ash, can only be done after industrial use tests.

\section{RESULTS AND DISCUSSION}

Analysis of the characteristics determined on the experimental batch will lead to the following assessments:

- The granulometry indicates an advanced fineness of the powder, because of mixing in the ball mill, although the ball load was $20 \%$ (of the total balls) which led to the advanced grinding of the coke and partially of the perlite; it is necessary to reduce the mixing time, to $15-20$ minutes, and to add the perlite only 5 minutes before the end of the homogenization.

- Granulometry indicates an advanced fineness of the powder because of mixing in a mill with balls, although the ball load was $20 \%$ (of all balls) which led to the advanced milling of the coke and partly of the perlite; it is necessary to reduce the mixing time to 1520 minutes and to add the perlite only 5 minutes before the end of mixing.

- The volumetric mass and spreading area are conditioned by performing advanced drying and have optimum values for a thermo insulating powder.
- The melting temperature is within the optimum range above $1300{ }^{\circ} \mathrm{C}$. It is important to consider in the manufacture of powder and the determination of components, the intended use, or more specifically the type of disperser, with or without a lid.

- For the dispenser with a lid, the thermal insulation function is largely taken over by the lid, and the coating powder in the dispenser must first ensure the purification of steel by capturing the inclusions.

- It is desirable for the dust to melt over a long period of time and for the melting temperature to be as high as possible so that the powder melts do not occur within a few minutes.

- The content of oxides is specific to an ash-based powder and the melt has a higher share of oxides, corresponding to the burning consumption of coke. It should be specified that $\mathrm{MnO}$ is present in the powder, but also in the melt, in very small quantities, and the content of $\mathrm{Fe}_{2} \mathrm{O}_{3}$ in the melt is $7.60 \%$.

\section{CONCLUSIONS}

In order to research and make products of this type, with indigenous raw materials that include electric plant ash, the most widely used imported coating powders were taken as a reference in terms of composition, structure and properties

For the purposes of research and development of such products with indigenous raw materials including thermal electric plant ash, reference was made to the composition, structure and properties of the most used imported coating powders.

The use of this fine-grained waste deposited in dumps near coal-fired power plants a threefold beneficial effect has been obtained.

The first aspect is the much lower cost of ash as a raw material, being a production waste category, than traditional raw materials, with implications on the manufacturing cost of the coating powder.

A second favourable effect is that on the environment, the ash stored in dumps, having a very fine grain, is driven by air currents, and is polluting the air in a large area. Making the most of this waste is also greening the areas of the previous dump's locations.

The third favourable effect is to better thermal insulation and to capture non-metallic inclusions from continuously cast steel due to the slow melting of the coating powder that has had also thermal power plant ash in the raw materials recipe.

The results of the experimental research presented in this paper confirm the validity of the stated results and create the technological framework for the recovery and use of thermal electric plant ash as raw materials in the production of coating powders.

\section{REFERENCES}

[1] Ittu, S. (2013). Increasing the purity of steel by the efficient use of oxidic powders in the continuous casting plant dispenser. $\mathrm{PhD}$ thesis, Bucharest.

[2] Demir, I., Sevim, O., Ozel, G., \& Dogan, O. (2020). Microstructural, physical and mechanical properties of aerated concrete containing fly ash under high temperature 
and pressure. Romanian Journal of Materials, 50(2), 240249.

[3] Volceanv, E., Volceanov, A., \& Sandu, S. M. (2019. Influence of poplar ash and willow ash admixture on plastering mortar properties. Romanian Journal of Materials, 49(4), 591-600.

[4] Woraphot, P. \& Abideng, H. (2011). Feasibility study of cement composites with para wood particle wastes: strength and durability. Global nest journal, 13(2), 182-191. https://doi.org/10.30955/gnj.000768

[5] Ittu, C., Constantin, N., Miculescu, F., \& Dobrescu, C. (2009). Insulating powder used in iron and steel industry. Metalurgia International, 14(4) 25-28.

[6] Ardelean, E., Lăscuţoni, A., Ardelean, M., Socalici, A., \& Hepuţ, T. (2016). Simulation of solidification process for billet with $\phi 350 \mathrm{~mm}$ section, continuous casted. IOP Conference Series: Materials Science and Engineering, 106(1). https://doi.org/10.1088/1757-899X/106/1/012034

[7] Louhenkilpi, S. et al. (2003). Effect of thermophysical material data on heat transfer in continuous casting. Modeling of casting, welding and advanced solidification processes- $X, 733-740$.

[8] Ittu, S. et al. (2021). Experimental research for testing the behavior in industrial conditions of cenoterm coating powders used for continuous casting of steel. Romanian journal of materials, 51(2), 291-299.

[9] Palomo, A., Maltseva, O., \& Fernandez. A. (2016). Ultra reactive ash: a new concept of fly ash leading to the production of durable and cheap eco concrete. Romanian Journal of Materials, 46(3), 259-268.

[10] Ardelean, M., Lăscuțoni, A., Ardelean, E., \& Socalici, A. (2016). Liquidus temperature, optimization, powder coating, powder molding, steel continuous casting. Solid State Phenomena, 254, 176-181.

https://doi.org/10.4028/www.scientific.net/SSP.254.176

[11] Cwudziński, A. (2020). Physical modelling of fluids' interaction during liquid steel alloying by pulse-step method in the continuous casting slab tundish. Ironmaking \& Steelmaking, Processes, Products and Applications, 47(10), 1188-1198. https://doi.org/10.1080/03019233.2019.1708670

[12] Pineda Huitron, R. M., Ramirez Lopez, P. E., \& Vuorinen, E. (2019). Converging criteria to characterize crack susceptibility in a micro-alloyed steel during continuous casting. Materials Science \& Engineering A, 772, 138691. https://doi.org/10.1016/j.msea.2019.138691

[13] Ardelean, E., Lascutoni, A., Ardelean, M. et al. (2015). Technological aspects at continuous casting of semi-finished products with phi $270 \mathrm{~mm}$. IOP Conference Series-Materials Science and Engineering, 85, 012002. https://doi.org/10.1088/1757-899X/85/1/012002
Cristian DOBRESCU, Lecturer, PhD

University POLITEHNICA of Bucharest,

313, Splaiul Independenței, 060042

E-mail: cristiandobrescu@yahoo.com

Dragoș Florin MARCU, Associate Professor, PhD

University POLITEHNICA of Bucharest,

313, Splaiul Independenței, 060042

E-mail: dragos.marcu@arasnet.ro

\section{Contact information:}

Nicolae CONSTANTIN, Professor, PhD University POLITEHNICA of Bucharest

313, Splaiul Independenți, 060042

E-mail: nctin2014@yahoo.com

Valeriu RUCAI, Associate Professor, PhD

(Corresponding author)

University POLITEHNICA of Bucharest,

313, Splaiul Independentei, 060042

E-mail: vrucai@gmail.com

Bogdan FLOREA, Lecturer, PhD

University POLITEHNICA of Bucharest,

313, Splaiul Independentei, 060042

E-mail: florea_b2004@yahoo.com 